\title{
SUBSURFACE STRUCTURES AND THE EFFECT ON FLEXIBLE PAVEMENT PERFORMANCE: THE SHAGAMU- BENIN EXPRESSWAY, SOUTHWESTERN NIGERIA, AS CASE STUDY.
}

\author{
Fatoba J.O ${ }^{1}, \quad$ Olorunfemi M.O ${ }^{2}$ and Eluwole A. B ${ }^{3}$ \\ 1 Dept. of Earth Sciences, Olabisi Onabanjo University, Ago-Iwoye, Ogun-State, Nigeria. \\ 2 Dept. of Geology, Obafemi Awolowo University, Ile-Ife, Osun-State, Nigeria. \\ 3 Dept. of Geology. Ekiti State University, Ado - Ekiti, Ekiti - State, Nigeria.
}

\begin{abstract}
Geoelectric and electromagnetic methods were conducted on failed highway pavement segments at Ilisan and Ore localities along Shagamu-Benin expressway. The objective was to determine the cause(s) of perpetual pavement failure along segment of the highway which have always defied rehabilitation.

Twenty schlumberger Vertical Electrical Soundings (VES) were carried out with the electrode spacing (AB/2) varying from $1 \mathrm{~m}$ to $75 \mathrm{~m}$ with the total spread of $150 \mathrm{~m}$. The VES data were presented as sounding curves and interpreted by partial curve matching technique and computer assisted 1-D forward modeling. The interpretation results of the VES were presented as geoelectric sections. 2-D resistivity imaging using Dipole-dipole array with electrode spacing (a) $=5 \mathrm{~m}$ and expansion factor $\mathrm{n}=1-5$ was conducted along the road segments and along the same profile with the VES. The 2-D resistivity imaging data were inverted using the Dipro software. VLF-EM inline profiling with station interval of $5 \mathrm{~m}$ was carried out to confirm the geologic features depicted by the VES and 2-D resistivity imaging. The VLF-EM results were presented as profiles.

The geoelectric sections identified the lateritic sand of resistivity values of $1230 \mathrm{ohm}-\mathrm{m}$ and an average thickness of about $2.2 \mathrm{~m}$ as the subgrade materials at Ilisan locality and partly weathered basement with resistivity values ranging from $283 \mathrm{ohm}-\mathrm{m}$ to $7848 \mathrm{ohm}-\mathrm{m}$ as the subgrade materials at Ore locality. The subgrade materials at both localities are adjudged competent to sustain the stability of the highway pavement. However, the 2-D resistivity imaging and VLF-EM identified low resistivity zones $(<100$ ohm-m), which diagnostic the presence of buried stream channel and shear zone suspected to be a fault beneath the subgrade materials at Ilisian and Ore localities respectively. These features may have been responsible for the flexible pavement failure always experienced at the investigated highway segments.
\end{abstract}

Keywords: Subsurface Structure, Subgrade Materials, VES, Resistivity and VLF-EM.

\section{INTRODUCTION}

The economy of any nation depends on the quality of her mode of transportation which involves movement of people and goods from one location to another. In countries where the development of these transportation infrastructures has followed a rational, coordinated and harmonized path, economic growth normally received a big boost (Beesley, 1973). In Nigeria where little attention is paid to rail and water way transportation, road transportation system has become their major means of mobility. The quality and extent of road network determine the mobility of people, goods and services within the country. The problem of failed road pavement has made it difficult, expensive and more arduous to move products and services from producer to consumers. This often leads to loss of human life, man-hours and high cost of goods and services. Road pavement failure can be attributed to engineering properties of subgrade materials, geology of the road route , hydrology/hydrogeology and geomorphology of the area traversed and usage factor (Ajayi, 1987; Meshida,1981; Madedor, 1993; Arumala and Akpokoje, 1987 and Teme et al, 1987).

The Shagamu - Benin road is a major highway that links Southwest to the Eastern part of the country. The widespread of pavement failures and cracks on this road have so much negative impact on the socioeconomic activities of the nation in that the road links the Southwest where the port city of Lagos is situated to the Eastern part of the country. Geoelectric and electromagnetic methods were conducted on failed highway pavement segments at Ilisan and Ore localities along Shagamu-Benin expressway. The objective was to determine the cause(s) of perpetual pavement failure along these segments of the highway which have always defied rehabilitation.

\section{DESCRIPTION OF THE HIGHWAY}

The studied highway is the Shagamu - Benin Highway, a strategic dual carriageway with a total length of about $260 \mathrm{~km}$. The road traverses Ogun, Ondo and Edo States of Nigeria and passes through the towns such as Shagamu, Ijebu-Ode, Ore, Ofosu and Benin City (See Fig. 1.1). The road traverses vegetation that varies from mixed savanna to dense forest. The climate is characteristic of coastal region of West Africa. The rainfall and 
humidity are high particularly from April to October. The mean annual rainfall varies from $1580 \mathrm{~mm}$ to 2900 $\mathrm{mm}$ (Akintola, 1986). The highway route has a flat to rolling topography with high water table in places. Essentially the topography comprises largely low land with an elevation that generally varies between $200 \mathrm{~m}$ and $400 \mathrm{~m}$ above sea level (Abam et al., 2005). The highway is underlain by the basement complex rocks of Southwestern Nigeria and sedimentary formations of the Dahomey Basin.

BbBasin, the Niger Delta and the Benin flank of the Anambra Basin.

\section{METHOD OF STUDY}

The highway segments were investigated using electrical resistivity method involving Vertical Electrical Sounding (VES), 2-D electrical imaging and VLF electromagnetic method of geophysical prospecting. One traverse was established at each of the localities investigated, made parallel to the road pavement, and allowed to cut across the stable and the failed segments of the highway. The direction of the traverses follows the orientation of the road. Twenty (20) VES points were occupied at the two localities, that is, ten VES at each location. The data were acquired by using PASI Earth Resistivity Meter (16 GL Digital Model). The Schlumberger array and 2-D electrical imaging using Dipole-Dipole configuration were adopted for the investigation. The electrode spacing $(\mathrm{AB} / 2)$ was varied from $1 \mathrm{~m}$ to $75 \mathrm{~m}$ giving a total spread of $150 \mathrm{~m}$. The VES were conducted at the spacing of $10 \mathrm{~m}$ along the traverse at both localities.

The VES data were presented in form of sounding curves. The apparent resistivity measurements at each station were plotted against electrode spacing on bi-logarithmic graph sheets. The resulting curves were then interpreted qualitatively and quantitatively. The qualitative interpretation involved visual inspection of the curve to determine the nature of the subsurface layering. Each curve was characterized depending on the number and the nature of the geoelectric layers. Typical VES curves acquired from the investigation are shown at Fig. 2.0 .

The quantitative interpretation involved the partial curve matching of the field curves. The results of the curve matching (layer resistivity and thicknesses) were fed into the computer as starting model parameters in 1-D forward modeling using the RESIST Version 1.0 Vander Velper (1988) software.

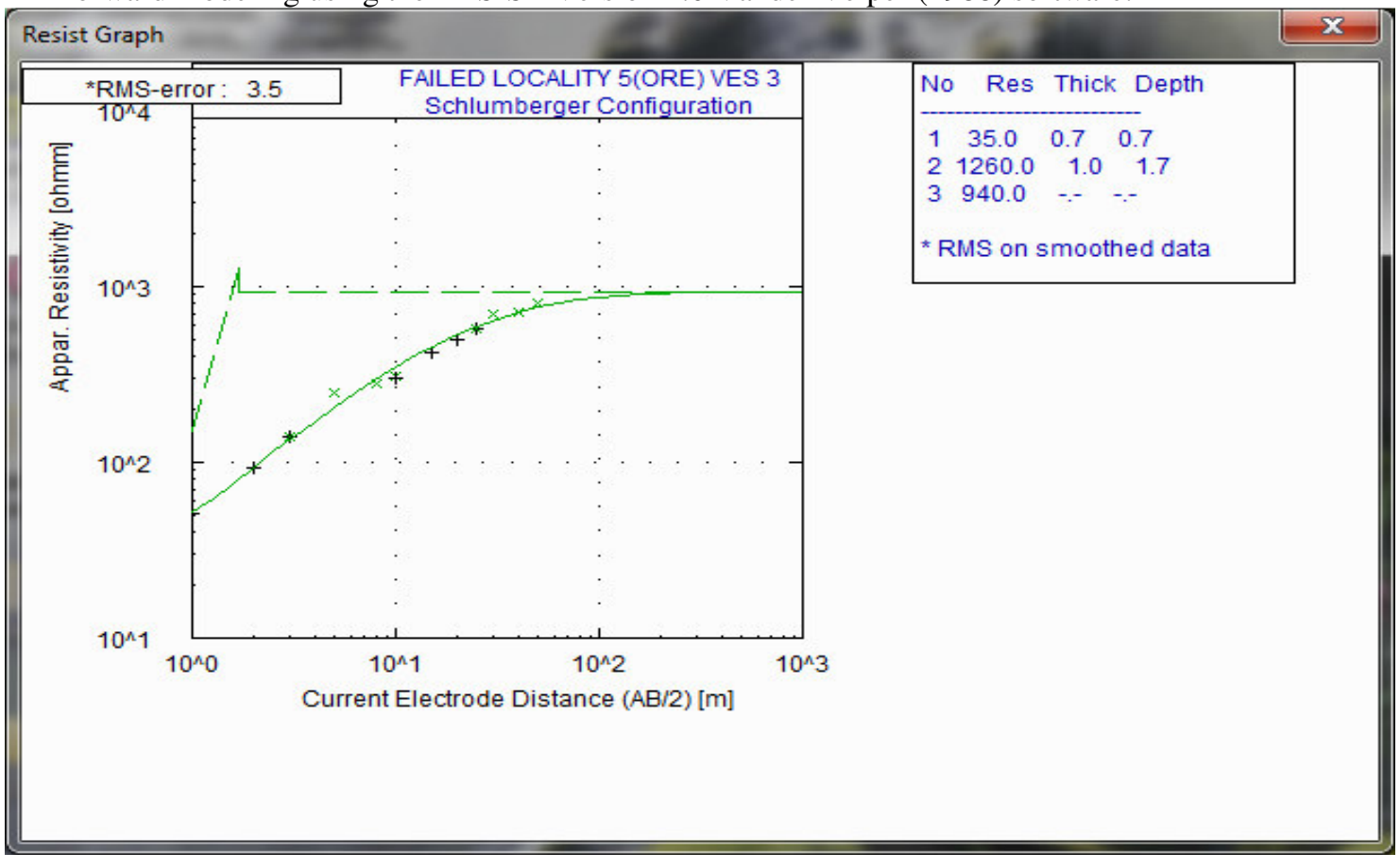




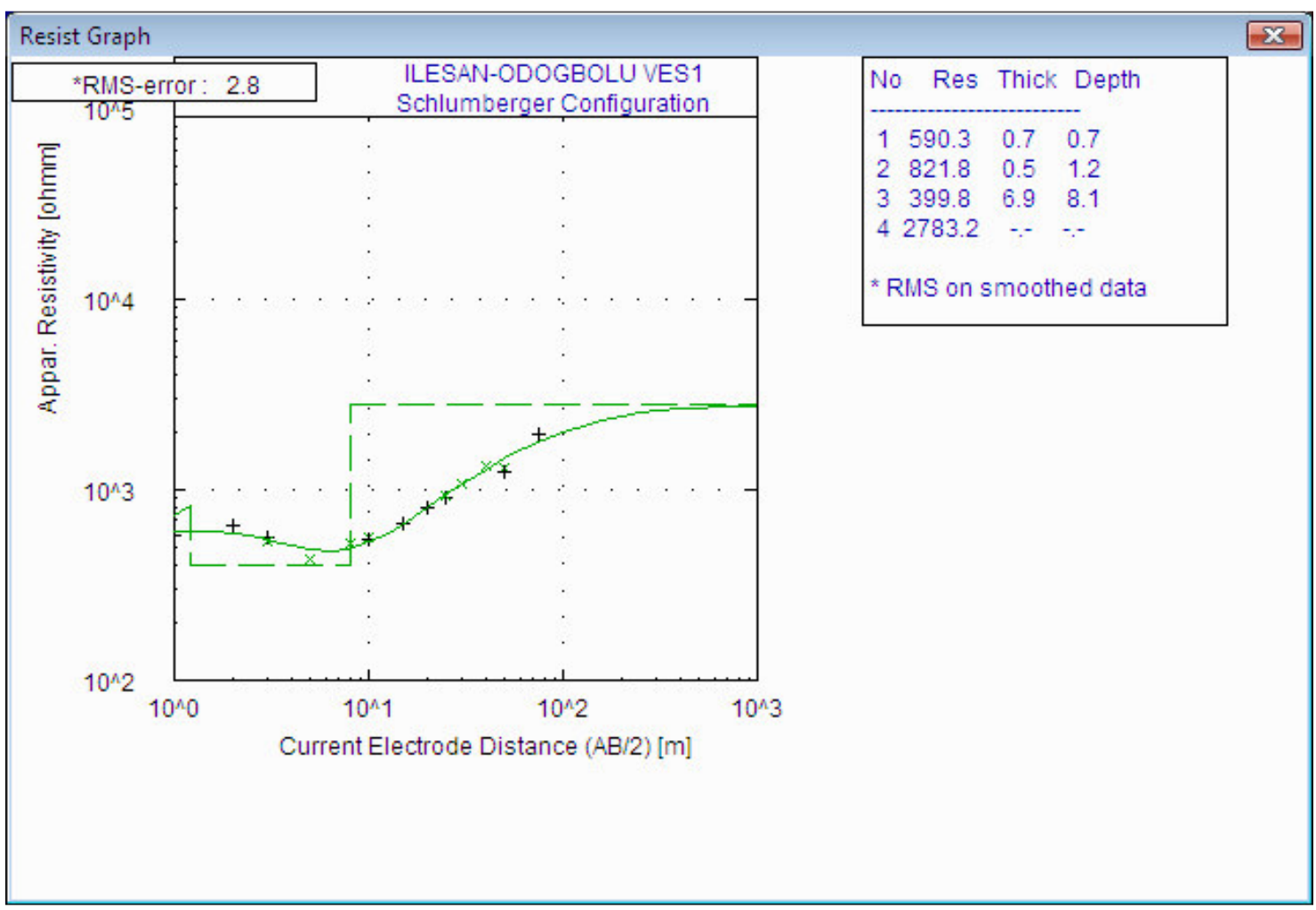

FIG.2.0: TYPICAL SOUNDING CURVE OF THE STUDY SEGMENT OF THE HIGHWAY

The 2-D resistivity imaging involving Dipole-Dipole profiling technique was adopted in this study to identified possible subsurface structures. The inter-electrode spacing of $5.0 \mathrm{~m}$ was adopted while inter-dipole separation factor (n) was varied from 1 to 5 . The technique is effective in the mapping of vertical discontinuities typical of jointed, fractured and faulted zones (Keller et al., 1975). The Dipole-Dipole field data were inverted to 2-D resistivity structure using 'DIPRO for Windows' software (2001).

The VLF-EM method utilized the inline profiling technique. The EM responses were taken at $5 \mathrm{~m}$ interval along the traverses. Twenty (20) stations were occupied at each locality. The Geonics EM 16 VLF equipment was used for the VLF measurements. A Fraser filter operator (Fraser, 1969) was applied on the real data to transform the data set to filtered real data using the equation

$Q_{i+1.5}=\left(Q_{i+3}+Q_{i+2}\right)-\left(Q_{i}+Q_{i+1}\right)$

Where $\mathrm{Q}$ is real component data and the subscript are the station positions where $\mathrm{i}$, the station number vary from 0 to $\mathrm{n}$.

The filtered real data transformed every genuine crossover or inflection point of the real anomaly to positive peak while the reverse crossover became negative peak.

The real and filtered real components were plotted against station positions using 'KHFFILT' software version 1.1a (2003). The 2-D inversion of the real component data was carried out to generate 2-D subsurface image using the same software.

\section{RESULTS AND DISCUSSION}

The interpretation results of the investigation are presented as geoelectric sections, 2-D resistivity imaging and VLF 2-D subsurface image in each locality, which are discussed below.

\section{ILISAN LOCALITY}

(a) Geoelectric Section

Figure 3.0a shows the geoelectric sections beneath Ilisan locality. The geoelectric section delineated four major geologic layers namely: the topsoil, lateritic sand, dry sand and sandstone.

The topsoil has resistivity values that vary from $468 \mathrm{ohm}-\mathrm{m}$ to $1026 \mathrm{ohm}-\mathrm{m}$. The thickness of the layer is between $0.5 \mathrm{~m}$ and $1.1 \mathrm{~m}$

The second layer has resistivity values varying from724 ohm-m to $1230 \mathrm{ohm}-\mathrm{m}$ and constitutes lateritic sand. The thickness of the layer is of between $0.3 \mathrm{~m}$ to $2.2 \mathrm{~m}$.

The dry sand formation constitutes the third layer with resistivity values that vary from $400 \mathrm{ohm}-\mathrm{m}$ to $880 \mathrm{ohm}$ $\mathrm{m}$. The layer thickness is between $6.9 \mathrm{~m}$ and $14.4 \mathrm{~m}$.

The fourth layer has resistivity value ranging from $2783 \mathrm{ohm}-\mathrm{m}$ to $10325 \mathrm{ohm}-\mathrm{m}$. The depth to the rock head 
varies from $8.1 \mathrm{~m}$ to $17.3 \mathrm{~m}$.

The entire road segment as displayed by the geosection is underlain by lateritic sand of high resistivity values, which constitutes the subgrade materials. The high resistivity values of the subgrade materials coupled with lower water table of the underlain layers, the entire road pavement should experience stability throughout the seasons.
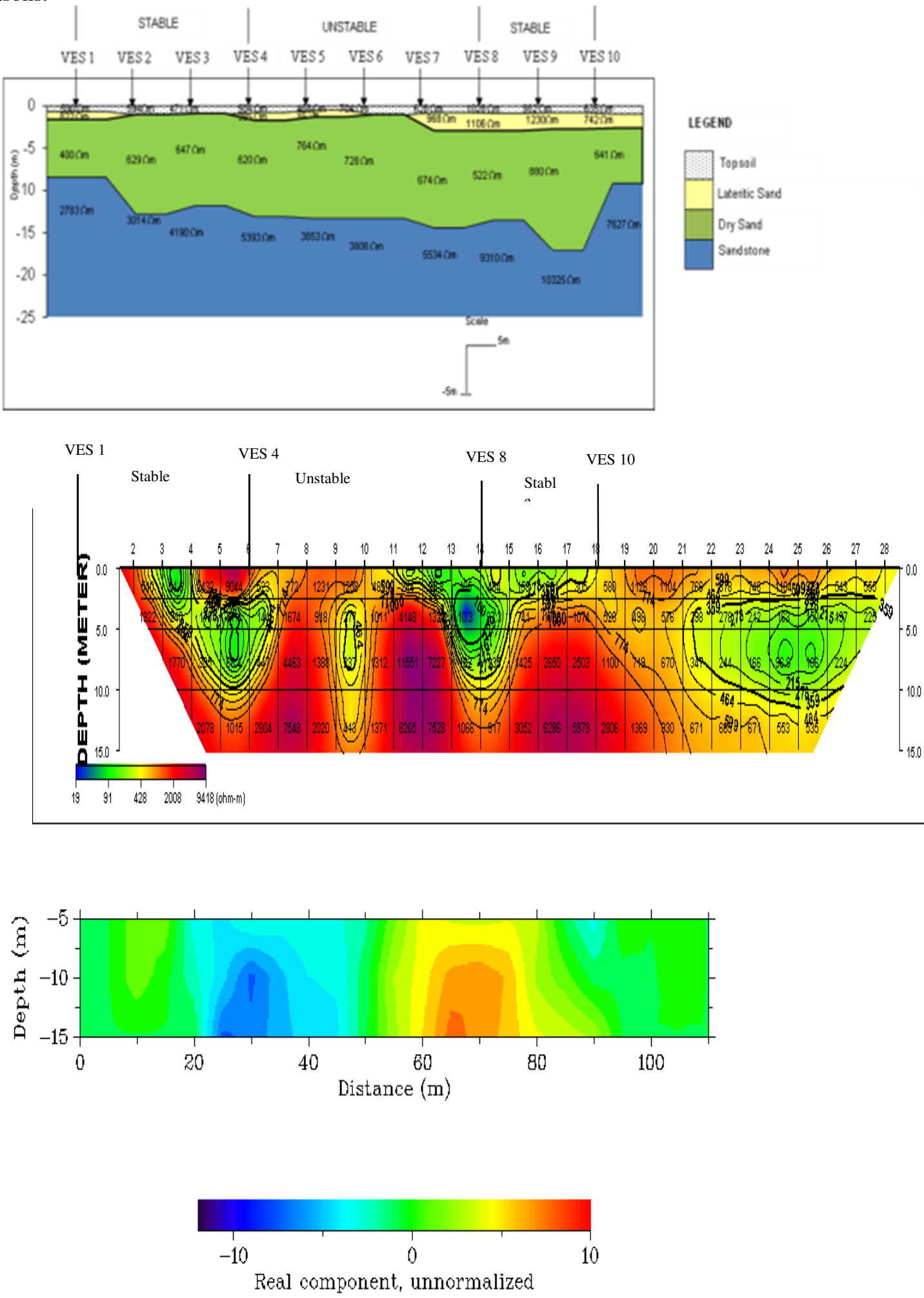

Fig.3.0 : (a) Geoelectric Section, (b) 2-D Dipole-Dipole Resistivity Structure and (c) 2-D Subsurface Image at Ilisan Locality. 
(b) 2-D Dipole-Dipole Resistivity Structure

The Dipole-Dipole 2-D resistivity structure at Ilisan Locality is displayed in Figure 3.0b.

The 2-D resistivity structure identifies three subsurface layers. The first layer is a very thin topsoil/laterite (in brownish/yellowish and green colour) and its resistivity is submerged in the second layer.

The second layer has resistivity values of between 90 and $11651 \mathrm{ohm}-\mathrm{m}$ indicating high lateral facies change. This layer extends to depth of up to $15 \mathrm{~m}$ and is in greenish/ yellowish / brownish colour. The third layer is the resistive basal unit suspected to be sand / sandstone. The near-surface low resistive zone, suspected to be due to an ancient river channel, is identified between stations 9 and 18 and may have been responsible for the pavement failure experienced in the area. The structure was later confirmed by conducting VLF-EM survey.

(c) 2-D Subsurface Image.

Figure $3 \mathrm{c}$ displays the 2-D subsurface image along failed locality 1 (Ilisan). The peak positive filtered real was identified at distances $50 \mathrm{~m}$ to $70 \mathrm{~m}$ corresponds to a weakly conductive linear target (light green) on the 2- D resistivity structure. This feature coincide with the linear feature identified on the 2-D resistivity image (Fig.3b) and suspected to be pavement failure precipitating by buried stream channel.

\section{ORE LOCALITY}

(a) Geoelectric Section

Figure 4a displays the geoelectric section of the VES results of Ore locality. The geoelectric section identifies three major geologic layers.

The topsoil has resistivity values that vary from $35 \mathrm{ohm}-\mathrm{m}$ to $88 \mathrm{ohm}-\mathrm{m}$ and thickness of between $0.6 \mathrm{~m}$ and 1.1 $\mathrm{m}$. The layer is composed of clay.

The partly weathered basement was delineated beneath VES 2, 6 and 7. The layer resistivity varies from 236 ohm-m to $633 \mathrm{ohm}-\mathrm{m}$. The thickness varies from $1.1 \mathrm{~m}$ to $2.2 \mathrm{~m}$.

The basement bedrock has resistivity values that range from $283 \mathrm{ohm}-\mathrm{m}$ to $7848 \mathrm{ohm}-\mathrm{m}$ and depth to the rock head of between $0.6 \mathrm{~m}$ and $1.1 \mathrm{~m}$.

The road pavement on this location which is virtually on the basement with high resistivity values ordinarily should experience stable pavement.

(b) 2-D Dipole-Dipole Resistivity Structure

Figure $4 \mathrm{~b}$ shows 2-D resistivity structure of Ore locality. The 2-D resistivity structure identified two major geologic layers which are the topsoil/weathered basement and basement bedrock. The topsoil/weathered layer (in greenish/blue colour) thickness averages about $2.5 \mathrm{~m}$ with resistivity values in the range of $46-800 \mathrm{ohm}-\mathrm{m}$. The basement bedrock in reddish brown/purple colour is near-surface as shown by the corresponding geoelectric section (Fig.4a). 

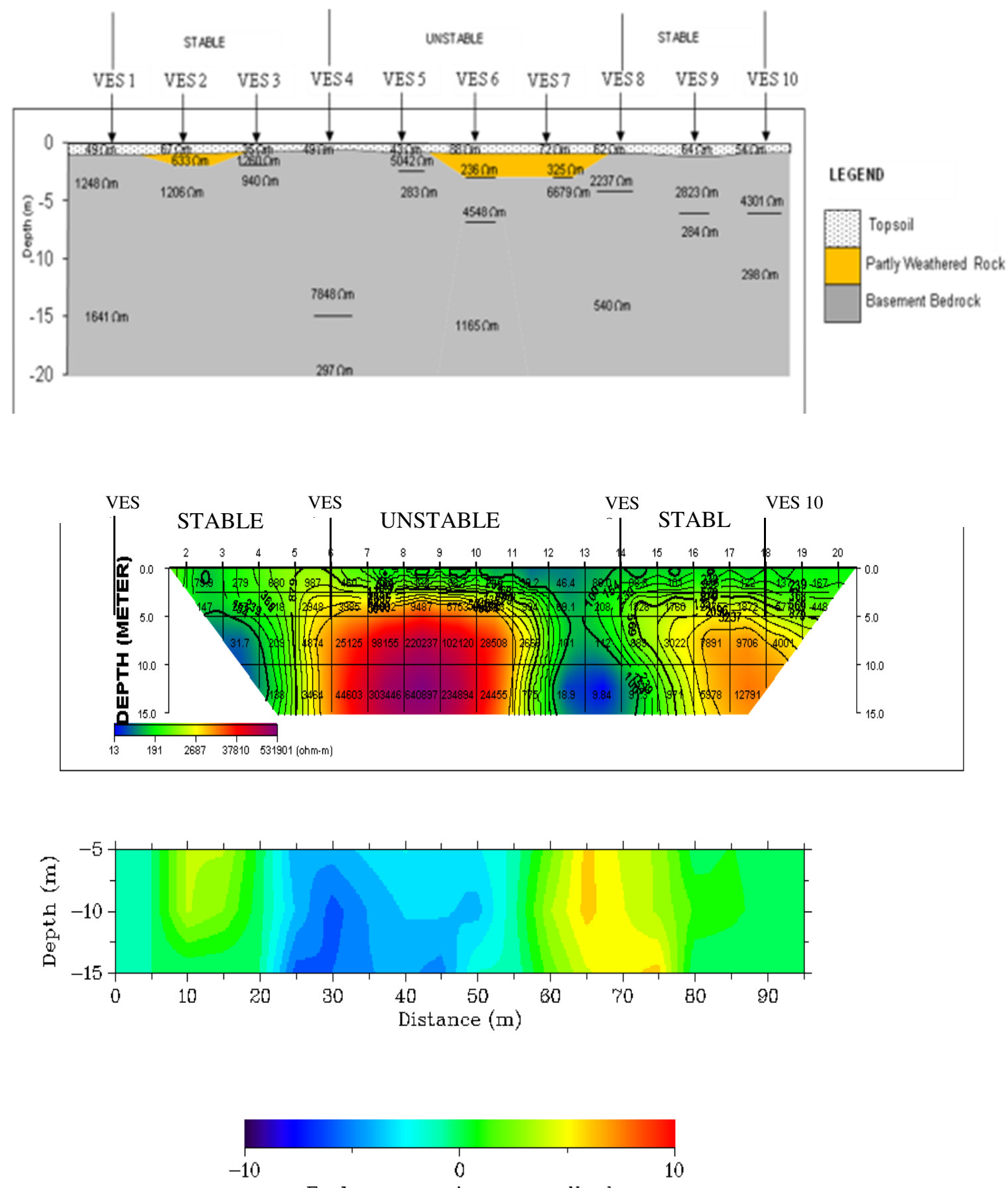

Real component, unnormalized

Fig. 4 : (a) Geoelectric Section, (b) 2-D Dipole-Dipole Resistivity Structure and (c) 2-D Subsurface Image at Ore Locality.

However, prominent vertical discontinuity suspected to be a fault or shear zone exists between stations 11 and 15. This suspected vertical structure extends to the surface as a low resistive zone and may have been responsible for the pavement failure along this segment. There is evidence of a similar vertical structure at the western segment between stations $0-5$ but whose very low resistivity zone in blue colour is at relatively deep depth of about $5 \mathrm{~m}$.

2-D Subsurface Image

The 2-D subsurface image along Ore locality is shown in Figure 3c. Fairly conductive target was identified from peak positive filtered real anomaly between distances $60 \mathrm{~m}$ and $80 \mathrm{~m}$ (Fig.4c). This target falls within the failed segment of the highway and coincides with linear geologic feature suspected to be a fault, delineated by the 2-D resistivity imaging (Fig.4b). This geologic feature may have precipitated the pavement failure along the investigated highway segment. 


\section{CONCLUSION AND RECOMMENDATION}

The widespread of pavement failure along Shagamu - Benin expressway has immense negative impact on the socio-economic activities of Nigeria, in that is the major road that links western part of the country to the eastern part. Geoelectric and electromagnetic methods were conducted along Ilisan and Ore localities of the highway segments which always defied rehabilitation.

The geoelectric sections identified the lateritic sand of resistivity values of $1230 \mathrm{ohm}-\mathrm{m}$ and an average thickness of about $2.2 \mathrm{~m}$ as the subgrade materials at Ilisan locality and partly weathered basement with resistivity values ranging from $283 \mathrm{ohm}-\mathrm{m}$ to $7848 \mathrm{ohm}-\mathrm{m}$ as the subgrade materials at Ore locality. The subgrade materials at both localities are adjudged competent to sustain the stability of the highway pavement. However, the 2-D resistivity imaging and VLF-EM identified low resistivity zones $(<100 \mathrm{ohm}-\mathrm{m})$, which diagnostic the presence of buried stream channel and shear zone suspected to be a fault beneath the subgrade materials at Ilisian and Ore localities respectively. These features may have been responsible for the flexible pavement failure always experienced at the investigated highway segments.

The results of the study have revealed that highway route failure can be precipitated by presence of buried features and not only the nature of subgrade materials as the highway engineers always suggest. Therefore, highway route selection and highway pavement failure investigation can best be carried out by geoscientific approaches. Hence, to complement the convectional geotechnical investigation of subgrade soils for highway route selection and highway pavement failure investigation. Comprehensive geophysical investigation involving VLF-EM and resistivity 1-D and 2-D imaging should be undertaken at regular interval of $250 \mathrm{~m}-1 \mathrm{~km}$ for proper study of subgrade soils and the linear feature within the subsurface along the proposed highway route and also at all the failed segments noted to have defied several rehabilitation efforts to allow proper diagnosis of the cause(s) of the failure and method to adopt for rehabilitation. The highway pavement suspected to be underlain by bedrock with linear features such as fracture/fault/lithological contact should be grouted.

\section{REFERENCES}

Abam, T. K. S.; Osadebe, C. C.; and Omange, G. N. (2005). Influence of Geology on pavement performance: A case study of Shagamu-Benin City Road, Southwestern Nigeria. Global Journal of Geological Sciences, Vol. 3 No. 1 , pp.52-56

Ajayi, L.A. (1987). Thought on Road failures in Nigeria. The Nigerian Engineer 22(1), pp 10-17.

Akintola, J.O. (1986). Rainfall Distribution in Nigeria (1892-1983). Impact Publisher Nigeria Limited, Ibadan, Nigeria.

Arumala, S.O and Akpokpdje E. G.(1987). Soil properties and pavement performance in the Niger Delta. Quarterly Journal of Engineering Geology, Vol 20,. pp. 287-296.

Beesley, M.E. (1973). "Urban Transport: Studies in Economic Policy" Research department occasional paper No 27, pp.3.

Fraser, S. J. and Green, A. A. (1987). A sofrware defoliant for geological analysis of band ratios. Int. J. Remote sensing. Vol. 8 (3). Pp 525 - 532.

Karous, M.R. and Hjelt, S.E. (1983). Linear filtering of VLF Dip Angle Measurements Geophysical Prospecting, 31: 782-794.

Madedor, A.C.(1983). Pavement Design Guidelines and Practice for different geological areas in Nigeria. In: Ola, S.A (ed) Tropical soil of Nigeria in Engineering practice A A Balkema, Rotterdam, pp. 291-297.

Meshida, E. A (1981). Laterite on the Highway - Understanding soil behaviour: West African Technical Review, pp. 245- 262.

Teme, S. C., Ajayi, O. O and Anowai, C. A. (1987). Geological control on highway pavement performance in Southwestern Nigeria: Proceedings of the ninth regional conference for Africa on Soil Mechanics and Foundation Engineering.

Vander Velper, B.P.A. (1988). Resist Version 1.0, MSc. Research Project, ITC, Delf Netherland. Vincent, R.K. (1987. Fundamentals of geological and environmental remote sensing, Prentice-Hall International (UK) Limited, London, 366p. 
The IISTE is a pioneer in the Open-Access hosting service and academic event management. The aim of the firm is Accelerating Global Knowledge Sharing.

More information about the firm can be found on the homepage:

http://www.iiste.org

\section{CALL FOR JOURNAL PAPERS}

There are more than 30 peer-reviewed academic journals hosted under the hosting platform.

Prospective authors of journals can find the submission instruction on the following page: http://www.iiste.org/journals/ All the journals articles are available online to the readers all over the world without financial, legal, or technical barriers other than those inseparable from gaining access to the internet itself. Paper version of the journals is also available upon request of readers and authors.

\section{MORE RESOURCES}

Book publication information: http://www.iiste.org/book/

Academic conference: http://www.iiste.org/conference/upcoming-conferences-call-for-paper/

\section{IISTE Knowledge Sharing Partners}

EBSCO, Index Copernicus, Ulrich's Periodicals Directory, JournalTOCS, PKP Open Archives Harvester, Bielefeld Academic Search Engine, Elektronische Zeitschriftenbibliothek EZB, Open J-Gate, OCLC WorldCat, Universe Digtial Library, NewJour, Google Scholar

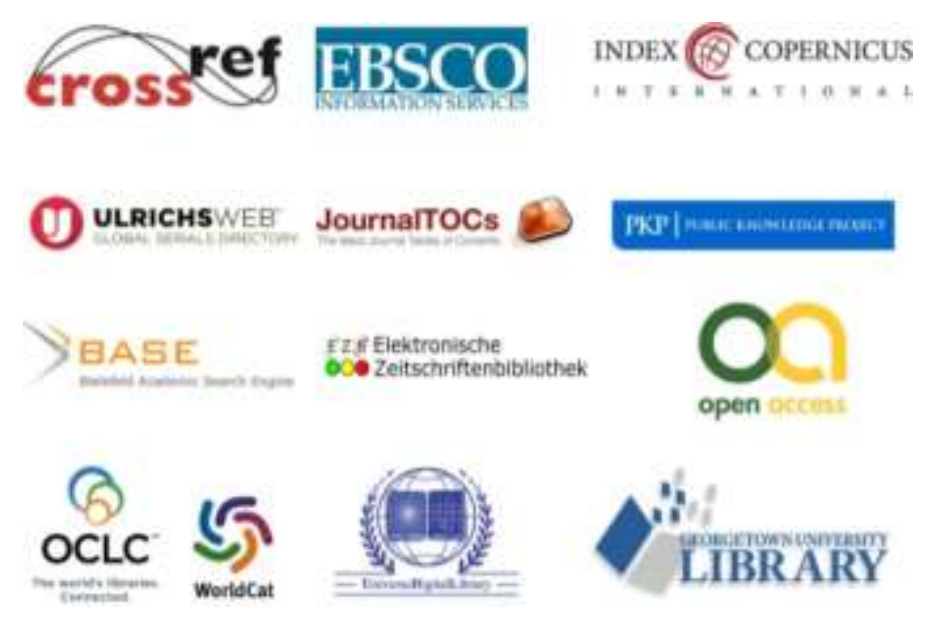

